\title{
Genitourinary Cancer
}

\section{Prognostic Significance of HE4 Tissue Expression in Serous Epithelial Ovarian Carcinoma}

\author{
Ankita Sethi ${ }^{1}$ Lalit Kumar $^{2}$ Sandeep Mathur ${ }^{3}$ Reeta Mahey ${ }^{1}$ Garima Kachhawa ${ }^{1}$ Neerja Bhatla ${ }^{1}$ \\ ${ }^{1}$ Department of Obstetrics and Gynaecology, All India Institute of \\ Address for correspondence Neerja Bhatla, MBBS, MD (Obstetrics \\ Medical Sciences, New Delhi, India \\ 2 Department of Medical Oncology, All India Institute of Medical \\ and Gynaecology), 3081, Teaching Block, AlIMS, Ansari Nagar, New \\ Delhi, India (e-mail: neerja.bhatla07@aiims.edu).
} Sciences, New Delhi, India

${ }^{3}$ Department of Pathology, All India Institute of Medical Sciences, New Delhi, India

\section{South Asian J Cancer 2022;11(2):125-132.}

\section{Abstract}

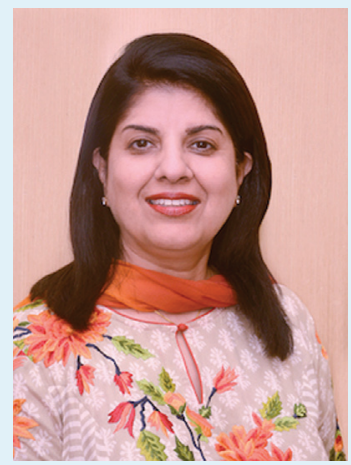

Neerja Bhatla
Keywords

- CA-125

- HE4 tissue expression

- human epididymis protein 4

- immunohistochemistry

- prognostic marker

- serous epithelial ovarian cancer
Background Human Epididymis protein 4 (HE4) is expressed in ovarian cancer. Preoperative serum testing is still not widely available. This pilot study aimed to investigate the magnitude of expression of HE4 in tissue sections of serous epithelial ovarian carcinoma, its correlation with clinical outcome, and the feasibility of HE4 immunohistochemistry as a prognostic marker.

Materials and Method In this ambispective study, immunohistochemistry (IHC) was used to evaluate tissue sections of ovarian serous epithelial carcinoma at primary cytoreductive surgery. On HE4 immunohistochemistry (IHC), the magnitude of HE4 expression was assessed categorically as high or low HE4 expression and semiquantitatively by the $\mathrm{H}$-score, and correlated with clinical outcome in terms of survival status, progression-free survival, and overall survival.

Results Of 32 cases, most $(n=31,96.8 \%)$ were positive for HE4 IHC. The mean age was $49 \pm 8.2$ years; 29 (90.6\%) patients were in FIGO stage IIIC; 25 (78.9\%) had $\geq 1 \mathrm{~cm}$ residual disease after surgery; 31 (96.8\%) received adjuvant chemotherapy, either 3-weekly ( $n=25$, $81.2 \%)$ or dose-dense weekly $(n=6,18.8 \%)$ regimen. The majority $(n=31,96.8 \%)$ had a high-grade tumor, of whom 19 (59.4\%) had high HE4 expression and 13(40.6\%) patients had $\mathrm{H}$-score in the range of 5 to 8 . The mean $\mathrm{H}$-score was $6.97 \pm 3.61$ (range 0 to 12). The overall survival of the study population at 64 months was $36.65 \%$ (95\% Cl: 8.59-66.34), with median overall survival of 59 months. A new scoring system was developed combining categorical HE4 expression and serum CA-125 levels; the combination of HE4 expression with postoperative CA-125 levels was found to be the best prognostic marker for overall survival $(p=0.05)$. A composite score of 2 identified patients with poor progression-free survival (HR 4.64, $p=0.039$ ) and overall survival (HR 5.45, $p=0.05$ ).

Conclusion The new composite scoring system using HE4 IHC with postoperative serum CA-125 levels offers an extremely useful option for prognosticating patients with serous epithelial ovarian carcinoma than serum CA-125 alone. This is useful where preoperative records are not available to the treating clinician.
DOI https://doi.org/10.1055/s-0042-1742711 ISSN 2278-330X

How to cite this article: Sethi A, Kumar L, Mathur S, et al. Prognostic Significance of HE4 Tissue Expression in Serous Epithelial Ovarian Carcinoma South Asian J Cancer 2022;11(2):125132.
(C) 2022. MedIntel Services Pvt Ltd. All rights reserved.

This is an open access article published by Thieme under the terms of the Creative Commons Attribution-NonDerivative-NonCommercial-License, permitting copying and reproduction so long as the original work is given appropriate credit. Contents may not be used for commercial purposes, or adapted, remixed, transformed or built upon. (https://creativecommons.org/licenses/by-nc-nd/ 4.0/)

Thieme Medical and Scientific Publishers Pvt. Ltd., A-12, 2nd Floor, Sector 2, Noida-201301 UP, India 


\section{Introduction}

Ovarian cancer is one of the leading causes of cancer-related mortality in women and ranks third among the malignant tumors of the female reproductive system. The majority of women present in the advanced stage of the disease (usually stage III, IV). ${ }^{1}$ The five-year survival is more than $90 \%$ when detected in stage I, which reduces to $28 \%$ in stages III and IV. ${ }^{2}$ Ovarian cancer treatment is primary cytoreductive surgery followed by adjuvant chemotherapy with platinum and taxane compounds or neoadjuvant chemotherapy followed by interval cytoreduction. ${ }^{3}$ Despite advances in management, the overall survival is still poor in most cases. ${ }^{4}$

New biomarkers are being assessed that may help to predict patients' clinical outcomes. Human epididymis protein 4 (HE4) is one such marker, found in 1999 to be significantly expressed in ovarian cancer and is a member of the Whey Acidic Protein (WAP) domain. ${ }^{5}$ HE4 was identified as a serum marker for ovarian cancer in $2003 .{ }^{6}$ Serous and endometrioid epithelial ovarian carcinoma have tissue overexpression of HE4. ${ }^{7}$ The human chromosome 20q1213.1 harbors the HE4 gene. The $20 \mathrm{q} 13$ chromosomal region is among the most frequently amplified regions in ovarian carcinomas, according to Comparative Genomic Hybridization (CGH) studies. ${ }^{8}$ Therefore, a definite correlation of HE4 with the pathogenesis of epithelial ovarian cancer is expected. According to recent studies, HE4 mainly influences the ability of ovarian cancer cells to invade and metastasize, ${ }^{9,10}$ which is a significant factor responsible for poor prognosis and overall survival. HE4 was first shown to be highly expressed in ovarian cancer and was identified as a serum marker by Hellstrom et al. ${ }^{6}$ Moore et al. analyzed serum and urine samples obtained before surgery from women with an adnexal mass for CA-125, HE4, inhibin, EGFR, SMRP, CA72-4, activin, osteopontin, and ERBB2 (Her2). When compared with final pathology results, serum HE4 had the highest sensitivity at 73\% and specificity at $95 \%$ and was found to be the single best marker for Stage I disease. ${ }^{11}$ Serum CA-125 and HE4 together showed the best sensitivity at $77 \%$ and specificity at $95 \%$. Drapkin et al. performed the first IHC study of tissue HE4 and found HE4 expression only in particular histologic subtypes, i.e., 93\% of serous, $100 \%$ of endometrioid epithelial ovarian carcinomas, only $50 \%$ of clear cell carcinomas, and none of the mucinous tumors were found to be HE4 positive. ${ }^{7}$ Galgano et al. examined the HE4 gene and protein expression in normal and malignant adult tissues using oligonucleotide microarray and tissue microarray. HE4 gene expression was significant in the normal human trachea and salivary gland, and to some extent in the lung, thyroid, pituitary gland, kidney, and prostate. The HE4 gene expression was highest in serous ovarian carcinomas among 175 human adult tumors. ${ }^{12}$ HE4 tissue expression was also found in a few pulmonary, breast, and endometrial adenocarcinomas, mesotheliomas, and less often, in gastrointestinal, renal, and transitional cell carcinomas.

Few studies have compared HE4 protein expression in epithelial ovarian carcinomas versus non-ovarian carcino- mas and normal tissues. ${ }^{7,13}$ Recent study by Orbo et al (2016) reported that changes in the HE4 tissue expression during progestin treatment helps in predicting the response to treatment or indicate progestin resistance for mediumand low-risk endometrial hyperplasia. HE4 is a novel tissue marker for therapy response and progestin resistance in medium- and low-risk endometrial hyperplasia. ${ }^{14}$

The present study was conducted to evaluate the magnitude of HE4 tissue expression in serous epithelial ovarian carcinoma and correlate it with progression-free survival and overall survival. To the best of our knowledge, this is the first study to correlate immunohistochemistry(IHC) with outcomes.

\section{Materials and Methods}

In this ambispective study, those patients were included who had primary ovarian serous epithelial carcinoma, who underwent primary cytoreductive surgery at our institution, during the period January 2010 to September 2015, and were on regular follow-up post-surgery for chemotherapy . These patients had detailed preoperative and postoperative followup records available at our institute. The following were the exclusion criteria: metastatic carcinoma to the ovary, borderline ovarian tumors, those who received neoadjuvant chemotherapy, tissue blocks were either not available or not in good condition, or whose intraoperative findings were incomplete.

Of 69 patients who fulfilled the inclusion criteria, tissue blocks of only 32 were available in good condition. Of these, 21 patients were retrospectively analyzed who underwent surgery between January 2010 and July 2013, and 11 patients who were operated on after July 2013 were followed prospectively till September 2015. In the case of patients who were lost to follow-up, telephonic contact was made to ascertain the patient's status and invite them for follow-up. In case the patient had expired, the date and cause of death were ascertained.

Progression-free survival is defined as the time from the date of surgery to the date of occurrence of any of the following events: the appearance of new lesion clinically, appearance of new lesion radiologically, CA-125 criteria of disease progression or death from any cause.

Platinum free interval defined as the time from the last cycle of chemotherapy to the date of occurrence of any of the following events: the appearance of new lesion clinically, the appearance of new lesion radiologically, CA-125 criteria of disease progression or death from any cause

Overall survival is defined as the length of time from either the date of diagnosis or the start of treatment/surgery for cancer, that patients diagnosed with the disease are still alive.

\section{Immunohistochemistry}

Tissue slides were de-paraffinized, rehydrated through graded alcohol, and quenched in $3 \% \mathrm{H}_{2} \mathrm{O}_{2}$. Antigen was retrieved by heating in a microwave at high power $(750 \mathrm{~W})$ in $10 \mathrm{mM}$ sodium citrate buffer for 3 cycles of 5 minutes each. The 
sections were kept with normal serum for 1 hour at room temperature. They then were incubated overnight at $4^{\circ} \mathrm{C}$ with HE4 antibody (monoclonal mouse IgG clone no.676013, $\mathrm{R}$ and D Systems, dilution 1:20). Human epididymis was taken as the positive control. In the negative control, the primary antibody was not applied. Negative control slides were processed simultaneously using a nonspecific immunoglobulin $\operatorname{IgG}$ at the same concentration as the primary antibody. The peroxidase-antiperoxidase method was used to process all the slides. We used diaminobenzidine as the final chromogen and used Gill's hematoxylin for counterstaining. ${ }^{15}$

\section{Evaluation of Immunohistochemical Expression}

The magnitude of HE4 expression in the serous epithelial ovarian carcinoma was analyzed categorically as high or low HE4 expression and semiquantitatively by the H-score. Cytoplasmic staining for intensity was graded $0-3$ as follows: $0=$ negative, $1=$ weak, $2=$ moderate, $3=$ strong. The percentage of positive cells was graded as $0-4$ as follows: $0=$ no positive cells, $1=1-24 \%, 2=25-49 \%, 3=50-74 \%$, and $4=75-100 \%$. The $\mathrm{H}$-score was calculated by multiplying the intensity by percentage of cells. ${ }^{12}$ The tissues were classified as high HE4 expression if $>50 \%$ of cells had strong cytoplasmic staining and low HE4 expression if $\leq 50 \%$ of cells had strong cytoplasmic staining.

\section{Outcome Parameters}

The primary outcomes were the magnitude of HE4 expression in serous epithelial ovarian carcinoma, correlation of HE4 expression with response to chemotherapy, progression-free interval, and overall survival. The secondary outcomes were the correlation of HE4 expression with baseline and postoperative S.CA-125 levels, histological type, and tumor grade.

\section{Ethical Approval}

The study was approved by the Institute Ethics Committee (RT-03/28.02.2014). Patients were provided with a patient information sheet and informed written consent was taken for included patients.

\section{Statistical Analysis}

Data were collected and recorded in a Microsoft Excel sheet. Statistical analysis was performed using STATA 11.0 (College Stations, Texas, and USA). Data were presented as number (percentage \%) or mean \pm standard deviation (SD)/median (minimum-maximum) as appropriate. The association between demographic and clinical variables with HE4 was tested using Chi-square/Fischer's exact test. The change in serum CA-125 from baseline to postoperative, post-3 and -6 cycles of chemotherapy was assessed using Wilcoxon signedrank test. The correlation coefficient was calculated between HE4 and postoperative serum CA-125 using Spearman's rank correlation coefficient. Kaplan-Meier curves were drawn to assess the correlation of progression-free survival and overall survival with the demographic and clinical variables, serum CA-125, and tissue HE4 expression. The log-rank test was used to compare the survival probabilities (progression-free survival, and overall survival). The hazard associated with demographic, clinical variables, serum CA-125 levels, and HE4 expression with respect to relapse and death was calculated using the Cox proportional hazards model. The results were reported as Hazard Ratio (95\% Confidence Interval). $\quad P$-value $<.05$ was considered statistically significant.

\section{Results}

The mean age of the study subjects was $49 \pm 8.2$ years. Most $(27 / 32,84.3 \%)$ patients were para 2 or 3 . The most common symptoms were abdominal distension and pain abdomen ( $n=25,78.1 \%)$, followed by mass abdomen $(n=16,50 \%)$. The majority ( $n=21,65.6 \%)$ patients had ascites and/or mass per abdomen $(n=16,50 \%)$ at presentation. The mean duration of symptoms was $3.1 \pm 2.2$ months with a range of $0.5-7$ months. Most $(n=20,62.5 \%)$ patients presented with $<3$ months of duration of symptoms, and $93.7 \%$ of patients presented within six months.

\section{Surgical Procedure}

All patients underwent staging laparotomy and cytoreductive surgery. Total abdominal hysterectomy and bilateral salpingo-oophorectomy were done in 30 (93.7\%) patients. In one patient, a subtotal hysterectomy was done due to extensive pelvic adhesions. Infracolic omentectomy was done in all except two cases. Seven patients underwent pelvic / para-aortic lymphadenectomy. Twenty-five (78.9\%) patients had $\geq 1 \mathrm{~cm}$ of residual disease after surgery.

\section{Histopathology and Surgicopathological Staging}

All 32 patients had serous epithelial ovarian carcinoma, of whom 31 (96.8\%) had high-grade tumors. The majority ( $n=29,90.6 \%)$ of patients were in FIGO stage IIIC.

\section{Adjuvant Chemotherapy}

Of the 32 patients, 31 (96.8\%) received adjuvant chemotherapy, either 3 -weekly $(n=25,81.2 \%)$ or dose-dense weekly $(n=6,18.8 \%)$ regimen of paclitaxel and carboplatin. One patient was advised chemotherapy but never returned for further treatment and died four months later.

\section{HE4 Immunohistochemistry (IHC)}

The majority ( $n=31,96.8 \%$ ) of cases of serous epithelial ovarian carcinoma were positive for HE4 IHC. There was no correlation between the volume of residual disease and HE4 IHC. The magnitude of HE4 expression in serous epithelial ovarian carcinoma was reported both as semiquantitative analysis by the H-score and a categorical analysis as high or low HE4 expression.

HE4 Expression (High / Low): Most $(n=19,59.4 \%)$ patients had high HE4 expression. =Fig. 1 shows the HE4 immunohistochemistry.

$H$-score: Thirteen $(n=13,40.6 \%)$ patients had H-score in the range of 5 to 8 , with a mean of $6.97 \pm 3.61$ (range 0 to 12 ). 


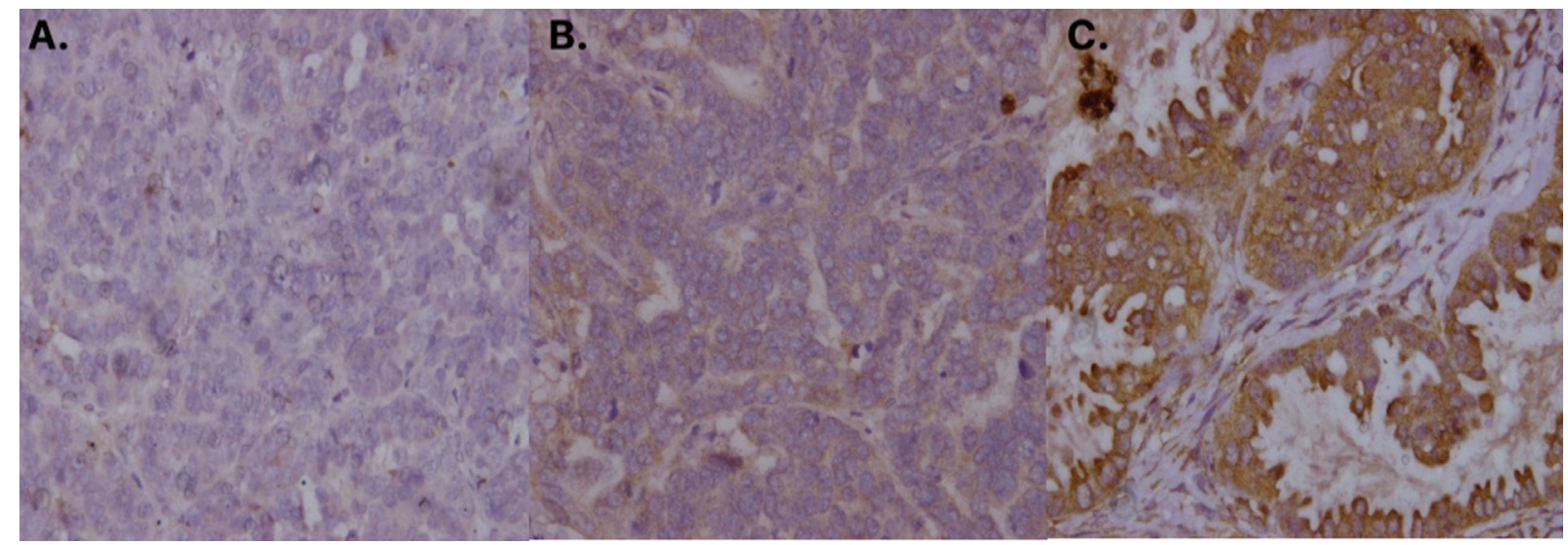

Fig. 1 (A-C) HE4 expression in serous epithelial ovarian carcinoma (at 40x). (A) Negative HE4 expression, (B) low HE4 expression, (C) high HE4 expression.

No significant correlation was found between the $\mathrm{H}$ score and the clinical outcome.

\section{Comparison between Baseline, Postoperative and Post-chemotherapy Serum CA-125 Levels and Percentage of Fall}

The median baseline (pre-operative) serum CA-125 was $524.5 \mathrm{IU} / \mathrm{ml}$ (range $34-26125 \mathrm{IU} / \mathrm{ml}$ ). It was repeated in the postoperative period or before chemotherapy initiation (range of 7-90 days). Results were available for 30 patients (one patient expired, one patient failed to get the test before adjuvant chemotherapy). Serum CA-125 levels were then measured after 3 and 6 cycles of chemotherapy, and the percentage of falls was calculated. Following primary debulking surgery it was $69.1 \%$ in the postoperative period, after three cycles of chemotherapy it was $98.5 \%(P<.001)$, and after six cycles of chemotherapy it was $98.8 \%(P<.001)$.

The analysis shows a trend that the fall in serum CA-125 levels over various time points is more among low HE4 expressors than in high HE4 expressors, though not statistically significant $(P=.1578)$, which reflects a better response to chemotherapy among patients with lower HE4 expression.

\section{Survival Status versus HE4 Expression}

The survival probability of high expressors at 56 months was $48 \%$ and of low expressors was $61.5 \%$. The majority $(8 / 11$, 72.7\%) of patients who had died had high HE4 expression $(p=0.226)$.

\section{Tissue HE4 and Serum CA-125 Correlation}

There was no statistically significant correlation $(p=0.36)$.

\section{Tissue HE4 + Serum CA-125 Composite Scoring}

A new composite scoring system was developed, combining categorical HE4 expression and serum CA-125 to improve the accuracy of correlation with clinical outcomes. The median serum CA-125 level at baseline was $524 \mathrm{IU} / \mathrm{ml}$, and postoperatively it was $197 \mathrm{IU} / \mathrm{mL}$. Accordingly, cut-off levels at baseline and postoperatively were taken as $500 \mathrm{IU} / \mathrm{mL}$ and $200 \mathrm{IU} / \mathrm{mL}$, respectively. Serum CA-125 below and above the cut-off levels were assigned a score of 0 and 1 , respectively.
Similarly, low and high HE4 expression was assigned a score of 0 and 1 , respectively. The two values were then combined to form a composite score, ranging from 0 to 2 .

\section{Progression-Free Survival}

The PFS at 64 months was $18.26 \%$ (95\% CI: 5.20-37.61). The median PFS was 26 months (range 20-29 months). - Table 1 shows the correlation of PFS with tumor markers. -Fig. 2a and $b$ shows Kaplan-Meier survival estimates of PFS with composite scores of serum CA-125 and tissue HE4 expression at baseline and postoperatively. A composite score of 2 at baseline and postoperatively correlated with poor PFS with HR of $3.90(p=0.094)$ and $4.64(p=0.039)$ respectively.

\section{Overall Survival (OS)}

The overall survival of the study population at 64 months was $36.65 \%$ (95\% CI: 8.59-66.34), with median overall survival of 59 months. - Table 2 shows the correlation of overall survival with tumor markers. - Fig. 3a and b shows KaplanMeier survival estimates of overall survival with composite scores of serum CA-125 and tissue HE4 expression at baseline and postoperatively. A composite baseline score of 2 was associated with $57 \%$ survival at 56 months as compared with $100 \%$ survival with a score of $0(p=0.299)$. A composite postoperative score of 0 had better overall survival; a score of 2 had an HR of $5.45(p=0.05)$. Thus while baseline and postoperative serum CA-125, and tissue HE4 expression did not individually correlate with overall survival significantly, the new composite scoring system combining serum CA-125 and HE4 expression correlated significantly with progression-free survival and overall survival significantly making it the best prognostic marker.

\section{Discussion}

Recent studies have mainly focused on HE4 gene expression in ovarian carcinoma. ${ }^{9,10,16}$ In a recent prospective study, serum HE4 was serially measured during treatment and follow-up of high-grade ovarian cancer. Serum CA125 and HE4 were measured at baseline, at the start of each chemotherapy cycle, and during follow-up till signs of progression. 
Table 1 Correlation of progression-free survival with tumor markers

\begin{tabular}{|c|c|c|c|c|c|c|c|}
\hline \multicolumn{2}{|l|}{ Tumor characteristic } & \multirow{2}{*}{$\begin{array}{l}\text { Relapse } \\
N=19 \\
N(\%) \\
5 \text { (45.5\%) }\end{array}$} & \multirow{3}{*}{$\begin{array}{l}p \text {-Value } \\
0.025\end{array}$} & \multirow{3}{*}{$\begin{array}{l}\begin{array}{l}\text { Median } \\
\text { progression- } \\
\text { free survival } \\
\text { (in months) }\end{array} \\
38 \\
24\end{array}$} & \multirow{2}{*}{$\begin{array}{l}\text { Progression-free } \\
\text { survival } \\
\text { probability\% at } \\
28 \text { months } \\
(95 \% \mathrm{Cl}) \\
57.14 \% \\
(21.72-81.46)\end{array}$} & \multirow{2}{*}{$\begin{array}{l}\text { Hazard ratio } \\
(95 \% \mathrm{Cl}) \\
1\end{array}$} & \multirow{3}{*}{$\begin{array}{l}p \text {-Value } \\
0.036\end{array}$} \\
\hline \multirow[t]{2}{*}{$\begin{array}{l}\text { Baseline S.CA-125 } \\
\text { (IU/mL) }\end{array}$} & $\leq 500(n=11)$ & & & & & & \\
\hline & $\begin{array}{l}>500 \\
(n=20)\end{array}$ & $14(70 \%)$ & & & $\begin{array}{l}20.59 \% \\
(5.06-43.30)\end{array}$ & $\begin{array}{l}3.06 \\
(1.07-8.74)\end{array}$ & \\
\hline \multirow[t]{2}{*}{$\begin{array}{l}\text { Postoperative } \\
\text { S.CA-125 (IU/mL) }\end{array}$} & $\leq 200(n=15)$ & $8(53.3 \%)$ & \multirow[t]{2}{*}{0.012} & 38 & $\begin{array}{l}55.28 \% \\
(26.01-77.04)\end{array}$ & 1 & \multirow[t]{2}{*}{0.013} \\
\hline & $>200(n=14)$ & $9(60)$ & & 21 & $\begin{array}{l}11.36 \% \\
(0.63-39.38)\end{array}$ & $\begin{array}{l}3.78 \\
(1.32-10.84)\end{array}$ & \\
\hline \multirow[t]{2}{*}{ HE4 expression } & Low $(n=13)$ & $9(69.2 \%)$ & \multirow[t]{2}{*}{0.77} & 28 & $\begin{array}{l}36.67 \% \\
(11.32-63.0)\end{array}$ & 1 & \multirow[t]{2}{*}{0.77} \\
\hline & High $(n=19)$ & $10(52.6 \%)$ & & 26 & $\begin{array}{l}34.03 \% \\
(11.0-58.81)\end{array}$ & $\begin{array}{l}1.14 \\
(0.46-2.82)\end{array}$ & \\
\hline \multirow[t]{3}{*}{$\begin{array}{l}\text { Composite } \\
\text { baseline score }\end{array}$} & $0(n=4)$ & $2(50.0 \%)$ & \multirow[t]{3}{*}{0.165} & 38 & $\begin{array}{l}75.00 \% \\
(12.79-96.05)\end{array}$ & 1 & \\
\hline & $1(n=16)$ & $10(62.5 \%)$ & & 26 & $\begin{array}{l}44.44 \% \\
(17.12-68.90)\end{array}$ & $\begin{array}{l}3.03 \\
(0.64-14.36)\end{array}$ & 0.161 \\
\hline & $2(n=11)$ & 7 (63.63\%) & & 24 & $\begin{array}{l}25.93 \% \\
(3.89-57.04)\end{array}$ & $\begin{array}{l}3.90 \\
(0.79-19.17)\end{array}$ & 0.094 \\
\hline \multirow[t]{3}{*}{$\begin{array}{l}\text { Composite } \\
\text { postoperative score }\end{array}$} & $0(n=6)$ & $4(66.6 \%)$ & \multirow[t]{3}{*}{0.133} & 28 & $\begin{array}{l}50.00 \% \\
(11.09-80.37)\end{array}$ & 1 & \multirow[t]{3}{*}{$\begin{array}{l}0.450 \\
0.039\end{array}$} \\
\hline & $1(n=18)$ & $11(61.1 \%)$ & & 26 & $\begin{array}{l}37.82 \% \\
(14.29-61.50)\end{array}$ & $\begin{array}{l}1.56 \\
(0.49-5.02)\end{array}$ & \\
\hline & $2(n=8)$ & $4(50 \%)$ & & 15 & $\begin{array}{l}0.00 \% \\
(0.00-0.00)\end{array}$ & $\begin{array}{l}4.64 \\
(1.08-19.95)\end{array}$ & \\
\hline
\end{tabular}
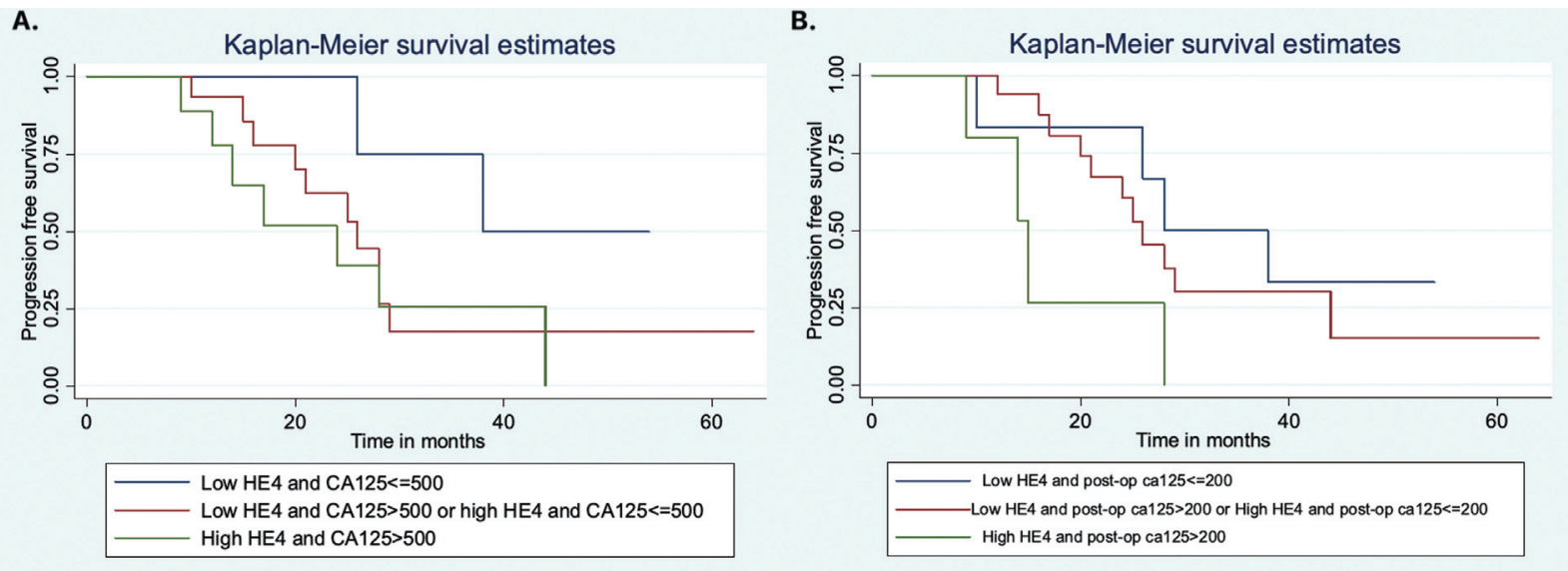

Fig. 2 Kaplan-Meier survival estimates of progression-free survival (PFS) versus tumor markers. (A) PFS vs Composite baseline score $(p=0.165)$. (B) PFS versus composite postoperative score $(p=0.133)$.

Baseline CA-125 and HE4 were compared with the tumor load found at the time of surgery and residual disease. They found that baseline serum HE4 differentiated between patients with a high tumor load from a low tumor load during surgery, which was statistically significant. Serum
HE4 level was found to be a statistically significant independent predictor of poor survival in the multivariate analysis. $^{17}$

As ours was an ambispective study, retrospective data were collected from January 2010 to July 2013, therefore, 
Table 2 Correlation of overall survival with S.CA-125 and HE4 expression

\begin{tabular}{|c|c|c|c|c|c|c|}
\hline \multicolumn{2}{|c|}{ Tumor characteristics } & \multirow{2}{*}{$\begin{array}{l}\text { Deaths } \\
N=11 \\
N(\%) \\
3(27.3 \%)\end{array}$} & \multirow{2}{*}{$\begin{array}{l}\text { Overall survival } \\
\text { probability at } \\
56 \text { months } \\
(95 \% \mathrm{CI}) \\
61 \% \\
(19.50-86.21)\end{array}$} & \multirow{3}{*}{$\begin{array}{l}p \text {-Value } \\
0.5189\end{array}$} & \multirow{2}{*}{$\begin{array}{l}\text { Hazard ratio }(95 \% \mathrm{Cl}) \\
1\end{array}$} & \multirow{3}{*}{$\begin{array}{l}p \text {-Value } \\
0.523\end{array}$} \\
\hline \multirow[t]{2}{*}{ Baseline CA-125 } & $\leq 500(n=11)$ & & & & & \\
\hline & $>500(n=20)$ & $8(40 \%)$ & $\begin{array}{l}50 \% \\
(20.70-74.18)\end{array}$ & & $\begin{array}{l}1.54 \\
(0.41-5.82)\end{array}$ & \\
\hline \multirow[t]{2}{*}{$\begin{array}{l}\text { Postoperative } \\
\text { CA-125 }\end{array}$} & $\leq 200(n=15)$ & $4(26.7 \%)$ & $\begin{array}{l}55 \% \\
(20.42-80.45)\end{array}$ & \multirow[t]{2}{*}{0.1043} & 1 & \multirow[t]{2}{*}{0.119} \\
\hline & $>200(n=14)$ & 7 (50\%) & $\begin{array}{l}48 \% \\
(15.59-75.92)\end{array}$ & & $\begin{array}{l}2.81 \\
(0.76-10.28)\end{array}$ & \\
\hline \multirow[t]{2}{*}{ HE4 expression } & Low $(n=13)$ & $3(23.1 \%)$ & $\begin{array}{l}61.5 \% \\
(19.65-86.51)\end{array}$ & \multirow[t]{2}{*}{0.2916} & 1 & \multirow[t]{2}{*}{0.303} \\
\hline & High $(n=19)$ & $8(42.1 \%)$ & $\begin{array}{l}48 \% \\
(19.59-73.02)\end{array}$ & & $\begin{array}{l}2.04 \\
(0.52-7.94)\end{array}$ & \\
\hline \multirow{3}{*}{$\begin{array}{l}\text { Composite } \\
\text { baseline score }\end{array}$} & $0(n=4)$ & $0(0.0 \%)$ & $100 \%$ & \multirow[t]{3}{*}{0.2987} & \multirow[t]{3}{*}{ Not applicable } & \\
\hline & $1(n=16)$ & $6(37.5 \%)$ & $\begin{array}{l}31 \% \\
(5.01-64.05)\end{array}$ & & & \\
\hline & $2(n=11)$ & $5(45.5 \%)$ & $\begin{array}{l}57 \% \\
(20.55-82.18)\end{array}$ & & & \\
\hline \multirow{3}{*}{$\begin{array}{l}\text { Composite } \\
\text { postoperative } \\
\text { score }\end{array}$} & $0(n=6)$ & $2(33.3 \%)$ & $\begin{array}{l}60 \% \\
(12.57-88.18)\end{array}$ & \multirow[t]{3}{*}{0.0083} & 1 & \\
\hline & $1(n=18)$ & $4(22.2 \%)$ & $\begin{array}{l}70 \% \\
(31.65-90.18)\end{array}$ & & $\begin{array}{l}0.85 \\
(0.14-5.19)\end{array}$ & 0.863 \\
\hline & $2(n=8)$ & $5(62.5 \%)$ & $\begin{array}{l}23 \% \\
(1.30-61.58)\end{array}$ & & $\begin{array}{l}5.45 \\
(0.98-30.02)\end{array}$ & 0.051 \\
\hline
\end{tabular}

A.

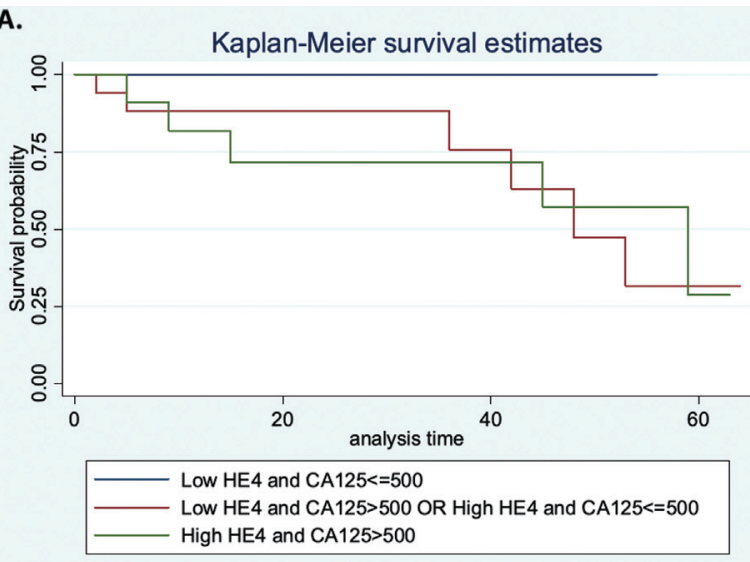

B.

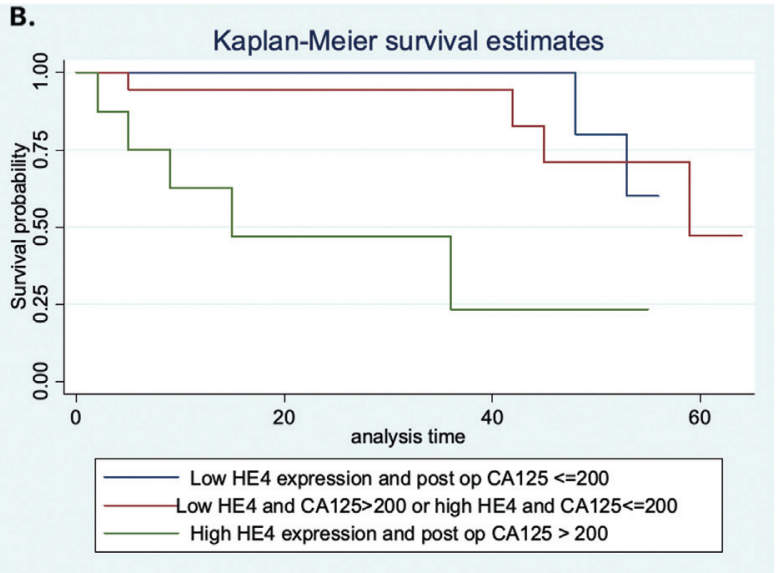

Fig. 3 Kaplan-Meier survival estimates of overall survival versus tumor markers. (A) Overall survival versus composite baseline score (at baseline) $(p=0.297)$ (B) Overall survival versus composite postoperative score $(p=0.0083)$.

serum HE4 levels were not available during this period. Data were collected prospectively from September 2013 to September 2015, during this time serum HE4 was not routinely done as a pre-operative workup, it was still being done in research settings and would have been costly.

However, IHC is more affordable and readily available, and therefore, we evaluated this method in the present study. This is useful where preoperative records or preoperative serum biomarkers are not available to the treating clinician, IHC can be done in the tissue blocks or slides. Lu et al. were the first to study the correlation of HE4 tissue expression with the patients' survival status though they did not correlate it with progression-free survival or overall survival. ${ }^{18}$ HE4 IHC was done in the tissue blocks of 32 patients. The majority ( $n=31,96.8 \%$ ) of serous epithelial ovarian carcinoma cases were positive for HE4 IHC. One patient with 
Table 3 Comparison of the composite postoperative score and postoperative CA-125 versus PFS and overall survival

\begin{tabular}{|c|c|c|c|c|c|}
\hline & \multirow[t]{2}{*}{ Clinical outcome } & \multicolumn{2}{|l|}{ PFS } & \multicolumn{2}{|c|}{ Overall survival } \\
\hline & & $\begin{array}{l}\text { Hazard ratio } \\
(95 \% \mathrm{Cl})\end{array}$ & $p$-Value & $\begin{array}{l}\text { Hazard ratio } \\
(95 \% \mathrm{Cl})\end{array}$ & $p$-Value \\
\hline \multirow[t]{3}{*}{ Composite postoperative score } & $0(n=6)$ & 1 & & 1 & \\
\hline & $1(n=18)$ & $\begin{array}{l}1.56 \\
(0.49-5.02)\end{array}$ & 0.450 & $\begin{array}{l}0.85 \\
(0.14-5.19)\end{array}$ & 0.863 \\
\hline & $2(n=8)$ & $\begin{array}{l}4.64 \\
(1.08-19.95)\end{array}$ & $0.039^{*}$ & $\begin{array}{l}5.45 \\
(0.98-30.02)\end{array}$ & $0.05^{*}$ \\
\hline \multirow[t]{2}{*}{ Postoperative S.CA-125 } & $\leq 200(n=15)$ & 1 & \multirow[t]{2}{*}{$0.013^{*}$} & 1 & \multirow[t]{2}{*}{0.119} \\
\hline & $>200(n=14)$ & $\begin{array}{l}3.78 \\
(1.32-10.84)\end{array}$ & & $\begin{array}{l}2.81 \\
(0.76-10.28)\end{array}$ & \\
\hline
\end{tabular}

negative HE4 expression had presented with abdominal pain, distension, nausea, vomiting, loss of weight, and loss of appetite. Serum baseline CA-125 was $1779 \mathrm{IU} / \mathrm{ml}$. Although the patient underwent suboptimal debulking with surgicopathological staging IIIC and histopathology suggestive of high-grade serous epithelial ovarian carcinoma, she had a complete response after six cycles of chemotherapy and had an overall survival of 53 months.

To the best of our knowledge, ours is the first study to correlate HE4 expression in ovarian tumors with clinical outcomes in terms of PFS and overall survival. In the present study, HE4 tissue expression tissue expression did not significantly correlate with stage, grade, type, and residual tumor. The HE4 expression did not correlate with the histological grade of the tumor in this study, as all were highgrade epithelial ovarian carcinoma.

The H-score was correlated with demographic and clinical variables; however, no significant correlations were seen. The mean H-score was $6.97 \pm 3.61$ with a range of 0 to 12 . It was not found to correlate with the patient's prognosis and clinical outcome in terms of PFS or overall survival. The categorical classification of HE4 expression as high and low HE4 expression was then studied and was found to be more useful as it correlated to some extent with the prognosis and clinical outcome of the patients. Serum CA-125 has already been proven to be a useful prognostic marker in detecting the recurrence of epithelial ovarian carcinoma ${ }^{19}$

The new composite scoring system which was developed, combining categorical HE4 expression and serum CA-125, was applied at baseline and postoperative time points. It was seen that this composite score was a better prognostic marker than serum CA-125 levels alone in terms of both PFS and OS. Patients with composite baseline score of 2 had an increased chance of relapse (HR 3.90, $p=0.094$ ). Patients with a composite postoperative score of 2 had a high probability of relapse (HR 4.64, $p=0.039$ ) and mortality (HR 5.45, $p=0.05$ ). - Table 3 shows the correlation of composite postoperative score with PFS and overall survival.

The study by Lu et al (2011), is the only other study that has correlated the HE4 tissue expression in ovarian carcinoma with survival status but did not compare progressionfree survival and overall survival as has been done in our study. Lu et al found that 25/61 (40.9\%) had high HE4 expression, and $68.0 \%(17 / 25)$ patients in the high-expresser group died of disease as compared with $36.1 \%$ (13/36) in the low-expresser group. Lu et al. concluded that the higher the HE4 expression, the poorer the survival status $(p<0.05) .{ }^{18}$ In our study, 19/32 (59.4\%) had high HE4 expression and $72.7 \%$ $(8 / 11)$ of those who died had high HE4 expression compared with $27.3 \%$ who had low expression $(p=0.226)$. Though not statistically significant, it did show a trend for the inverse correlation between HE4 expression and survival status.

Our study showed that the composite postoperative score had the best correlation with PFS and the overall survival of the patients, making it a good prognostic marker. This will be extremely useful to prognosticate the patients, especially those patients who present after surgery elsewhere and who have access to tissue blocks but may not have tested for tumor markers preoperatively. Several studies have shown that HE4 overexpression leads to tumorigenesis., ${ }^{9,10,16}$ Thus, it may also be useful for targeted gene therapy like HER2neu in breast carcinoma.

There were limitations of this study due to its ambispective design. Several subjects who were included retrospectively had to be excluded due to incomplete information and poor quality of tissue blocks, as they could not be used for HE4 IHC. Therefore, the resulting sample size was small. The cause of death could not be ascertained in all cases. Since serum HE4 was not done routinely, and no correlation could be determined between serum HE4 and HE4 IHC. Prospective studies with a larger sample size are needed to assess the correlation of preoperative serum CA-125, serum HE4, and HE4 IHC.

\section{Conclusion}

HE4 is highly expressed in serous epithelial ovarian carcinoma and correlates with poorer progression-free survival and overall survival. The new composite scoring system using HE4 IHC with postoperative serum CA-125 levels offers an extremely useful option for prognosticating patients with serous epithelial ovarian carcinoma than serum CA-125 alone. This is useful where preoperative records are not available to the treating clinician. HE4 
should be considered as a target for gene-based therapy for future studies.

\section{Conflict of Interest}

None declared.

\section{References}

1 Urban N, McIntosh MW, Andersen M, Karlan BY. Ovarian cancer screening. Hematol Oncol Clin North Am 2003;17(04):989-1005, ix

2 Jemal A, Siegel R, Ward E, et al. Cancer statistics, 2006. CA Cancer J Clin 2006;56(02):106-130

3 Eisenhauer EA, Vermorken JB, van Glabbeke M. Predictors of response to subsequent chemotherapy in platinum pretreated ovarian cancer: a multivariate analysis of 704 patients [seecomments]. Ann Oncol 1997;8(10):963-968

4 Partridge EE, Barnes MN. Epithelial ovarian cancer: prevention, diagnosis, and treatment. CA Cancer J Clin 1999;49(05):297-320

5 Schummer M, Ng WV, Bumgarner RE, et al. Comparative hybridization of an array of 21,500 ovarian cDNAs for the discovery of genes overexpressed in ovarian carcinomas. Gene 1999;238(02):375-385

6 Hellström I, Raycraft J, Hayden-Ledbetter M, et al. The HE4 (WFDC2) protein is a biomarker for ovarian carcinoma. Cancer Res 2003;63(13):3695-3700

7 Drapkin R, von Horsten HH, Lin Y, et al. Human epididymis protein 4 (HE4) is a secreted glycoprotein that is overexpressed by serous and endometrioid ovarian carcinomas. Cancer Res 2005;65(06): 2162-2169

8 Sonoda G, Palazzo J, du Manoir S, et al. Comparative genomic hybridization detects frequent overrepresentation of chromosomal material from 3q26, 8q24, and 20q13 in human ovarian carcinomas. Genes Chromosomes Cancer 1997;20(04):320-328

9 Lu R, Sun X, Xiao R, Zhou L, Gao X, Guo L. Human epididymis protein 4 (HE4) plays a key role in ovarian cancer cell adhesion and motility. Biochem Biophys Res Commun 2012;419(02): 274-280

10 Zhu Y-F, Gao G-L, Tang S-B, Zhang Z-D, Huang Q-S. Effect of WFDC 2 silencing on the proliferation, motility and invasion of human serous ovarian cancer cells in vitro. Asian Pac J Trop Med 2013;6 (04):265-272

11 Moore RG, Brown AK, Miller MC, et al. The use of multiple novel tumor biomarkers for the detection of ovarian carcinoma in patients with a pelvic mass. Gynecol Oncol 2008;108(02): 402-408

12 Galgano MT, Hampton GM, Frierson HF Jr. Comprehensive analysis of HE4 expression in normal and malignant human tissues. Mod Pathol 2006;19(06):847-853

13 Høgdall E. Cancer antigen 125 and prognosis. Curr Opin Obstet Gynecol 2008;20(01):4-8

14 Ørbo A, Arnes M, Lyså LM, Borgfeldt C, Straume B. HE4 is a novel tissue marker for therapy response and progestin resistance in medium- and low-risk endometrial hyperplasia. Br J Cancer 2016; 115(09):e15

15 Chang B, Liu G, Xue F, et al. ALDH1 expression correlates with favorable prognosis in ovarian cancers. Mod Pathol 2009;22(06): 817-823

16 Lokich E, Singh RK, Han A, et al. HE4 expression is associated with hormonal elements and mediated by importin-dependent nuclear translocation. Sci Rep 2014;4(01):5500

17 Salminen L, Gidwani K, Grènman S, et al. HE4 in the evaluation of tumor load and prognostic stratification of high grade serous ovarian carcinoma. Acta Oncol 2020;59(12):1461-1468

18 Lu M, Zhou J, Xu F, Yin Y, Chen D. The expression of human epididymis protein 4 and cyclindependent kinase inhibitor p27Kip1 in human ovarian carcinoma. Asian Biomedicine 2017; 5(06):765-774. Doi: 10.5372/1905-7415.0506.103

19 Piatek S, Panek G, Lewandowski Z, et al. Rising serum CA-125 levels within the normal range is strongly associated recurrence risk and survival of ovarian cancer. J Ovarian Res 2020;13(01):102 